\title{
Analgesic drugs: What quality of information is present on the Internet?
}

\author{
Medicamentos analgésicos: Qual a qualidade da informação presente na Internet? \\ Fármacos analgésicos: ¿Qué calidad de información hay en Internet?
}

Received: 06/14/2021 | Reviewed: 06/24/2021 | Accept: 06/28/2021 | Published: 07/11/2021

\author{
Ana Amélia Rangel Ribeiro \\ ORCID: https://orcid.org/0000-0002-0565-3284 \\ Fluminense Federal University, Brazil \\ E-mail: anameliarib@gmail.com \\ Gustavo Leite Magalhães de Melo \\ ORCID: https://orcid.org/0000-0001-7006-0963 \\ Fluminense Federal University, Brazil \\ E-mail: gustavomeloufrj@gmail.com \\ Merielle de Souza Costa \\ ORCID: https://orcid.org/0000-0003-0467-1197 \\ Fluminense Federal University, Brazil \\ E-mail: costa.mere@gmail.com \\ Miriam Furtado de Oliveira Lima \\ ORCID: https://orcid.org/0000-0001-9154-7359 \\ Fluminense Federal University, Brazil \\ E-mail: miriamfurtadodeoliveiralima@gmail.com \\ Renan da Silva Gianoti Torres \\ ORCID: https://orcid.org/0000-0003-2590-1289 \\ Fluminense Federal University, Brazil \\ E-mail: gianoti.r@gmail.com \\ Sabrina Calil-Elias \\ ORCID: https://orcid.org/0000-0002-2026-1510 \\ Fluminense Federal University, Brazil \\ E-mail: sabrinacalil@id.uff.br
}

\begin{abstract}
The internet enables the search for several subject types, including health and drug utilization. These information are spread generally without reliability and scientific basis, that can encourage self-medication and indiscriminate medicine use. This was a cross-sectional study, carried out through application of tools that evaluated the quality of global health information and the specific content about analgesic drugs on 98 Brazilian websites. Among the most cited drugs on websites, nonsteroidal anti-inflammatory drugs $(83.67 \%)$, acetaminophen $(47.96 \%)$ and opioids $(47.96 \%)$ stood out. All websites described pharmacological treatment options for pain, however, most websites did not mention any adverse reactions or contraindications for painkillers use. Information on opioid addiction and tolerance risk was present only in $18.37 \%$ of websites. Considering all the indicators evaluated, no website was considered to be of good quality, even those with a quality certification seal. These results showed important shortcomings on health and drugs information published on internet, which can lead to analgesics inappropriate use, adverse effects and even intoxications events. This reinforces the need to control this information and to adopt minimum quality criteria for the websites, aiming to minimize health risks, drug irrational use and to contribute for lay public's safety.
\end{abstract}

Keywords: Internet; Drug utilization; Information; Pain; Analgesics.

\section{Resumo}

A internet possibilita a busca por diversos tipos de assuntos, incluindo saúde e uso de medicamentos. Essas informações são difundidas geralmente sem confiabilidade e embasamento científico, o que pode estimular a automedicação e o uso indiscriminado de medicamentos. Trata-se de um estudo transversal, realizado por meio da aplicação de ferramentas, que avaliou a qualidade da informação global em saúde e o conteúdo específico sobre analgésicos em 98 sítios eletrônicos brasileiros. Dentre os medicamentos mais citados nos sítios eletrônicos, destacaram-se os anti-inflamatórios não esteroidais $(83,67 \%)$, paracetamol $(47,96 \%)$ e opioides $(47,96 \%)$. Todos os sítios eletrônicos descreviam opções de tratamento farmacológico para a dor, no entanto, a maioria dos sítios eletrônicos não mencionava quaisquer reações adversas ou contra-indicações para o uso de analgésicos. Informações sobre dependência de opioides e risco de tolerância estavam presentes em apenas 18,37\% dos sítios eletrônicos. Considerando todos os indicadores avaliados, nenhum sítio eletrônico foi considerado de boa qualidade, mesmo aqueles com selo de certificação de qualidade. Esses resultados evidenciaram deficiências importantes nas informações de saúde e medicamentos publicadas na internet, que podem levar ao uso inadequado de analgésicos, 
efeitos adversos e até eventos de intoxicação. Isso reforça a necessidade de controle dessas informações e da adoção de critérios mínimos de qualidade para os sites, visando minimizar os riscos à saúde, o uso irracional de medicamentos e contribuir para a segurança do público leigo.

Palavras-chave: Internet; Uso de medicamentos; Informação; Dor; Analgésicos.

\section{Resumen}

Internet permite la búsqueda de varios tipos de temas, incluida la salud y la utilización de medicamentos. Esta información se difunde generalmente sin confiabilidad y base científica, lo que puede fomentar la automedicación y el uso indiscriminado de medicamentos. Se trata de un estudio transversal, realizado mediante la aplicación de herramientas, que evaluó la calidad de la información global de salud y el contenido específico sobre analgésicos en 98 sitios web brasileños. Entre los fármacos más citados en los sitios web se destacaron los antiinflamatorios no esteroideos $(83,67 \%)$, el paracetamol $(47,96 \%)$ y los opioides $(47,96 \%)$. Todos los sitios web describieron opciones de tratamiento farmacológico para el dolor, sin embargo, la mayoría de los sitios web no mencionaron reacciones adversas o contraindicaciones para el uso de analgésicos. La información sobre la adicción a los opioides y el riesgo de tolerancia estuvo presente solo en el $18,37 \%$ de los sitios web. Considerando todos los indicadores evaluados, ningún sitio web fue considerado de buena calidad, incluso aquellos con sello de certificación de calidad. Estos resultados mostraron deficiencias importantes en la información sobre salud y medicamentos publicada en Internet, que pueden llevar a un uso inadecuado de analgésicos, efectos adversos e incluso intoxicaciones. Esto refuerza la necesidad de controlar esta información y adoptar criterios mínimos de calidad para los sitios web, con el objetivo de minimizar los riesgos para la salud, el uso irracional de los medicamentos y contribuir a la seguridad del público lego.

Palabras clave: Internet; Utilización de medicamentos; Información; Dolor; Analgésicos.

\section{Introduction}

Pharmacological pain treatment is recommended based on the analgesic ladder proposed by the World Health Organization (Horgas, 2017; Ng \& Cashman, 2018). The patient's evaluation and pharmacological therapy adjustments must be performed frequently according to a clinical condition (Cox, 2010). The analgesic ladder presents as basic principles the slow introduction and titration in the use of analgesics, through escalation and de-escalation between the classes of drugs used in pain control. Analgesics, nonsteroidal anti-inflammatory drugs (NSAIDs), adjuvants (antidepressants and anticonvulsants), and opioids (weak and strong) are arranged in ascending levels for sequential use and directly proportional to the intensity of the pain presented (Horgas, 2017; Ng \& Cashman, 2018).

In Brazil, in 2017, the Internet was used by $69.8 \%$ of the population, covering $74.9 \%$ of permanent households (Instituto Brasileiro de Geografia e Estatística [IBGE], 2018). According to data published by the Brazilian Internet Steering Committee, health-related information is listed among the five most searched topics on the World Wide Web (Comitê Gestor da Internet no Brasil [CGI], 2019).

Focosi and Souza (2016) conducted document analysis research using Google for data collection to map the information about pain found by Brazilians in the virtual environment. Their results indicated that the Internet is a source of health information increasingly used by the population, including pain-related content.

Electronic websites play an essential role in the dissemination of health and drug content, characterizing the Internet as a space that allows interaction between users, with the exchange of personal experiences and spread of data on prevention, diagnosis, and treatment of diseases (Moretti et al., 2012). The amount of information made available has been expanding more and more, but it generally lacks reliability and a scientific basis (Pereira Neto et al., 2013).

This scenario may encourage self-medication and indiscriminate use of drugs, especially non-prescription, easily accessible, and widely available drugs, such as some painkillers (Arrais et al., 2016). Besides, the marketing associated with controlled medications, such as opioids, antidepressants, and anticonvulsants, can boost illicit use in an abusive way, exposing individuals to the risks of dependence, tolerance, and intoxication (United Nations Office on Drugs and Crime [UNODC], 2019).

Thus, it is evident the importance of research to evaluate information about medicines published on the Internet and 
their possible influence on the use by the population, to determine the need to control this content (Mendonça \& Pereira Neto, 2015). In this context, the present study aimed to evaluate the quality of information on analgesic drugs published on Brazilian websites.

\section{Methodology}

This is a cross-sectional study, divided into three stages: search for websites with content related to the pharmacological treatment of pain, using a combination of keywords and Boolean operators in two search engines; selection of websites for analysis, applying exclusion criteria; and evaluation of the selected websites using tools that helped to analyze them. The first tool, adapted from the instrument developed by Mendonça and Pereira Neto (2015), contained sentences with minimum criteria and indicators for assessing the quality of health information transmitted on the Internet. In the second tool, the sentences focused on evaluating the pharmacological content of analgesic medications and was based on information from clinical protocols and international therapeutic guidelines aimed at the treatment of pain.

The search of electronic websites was carried out using the search engines Google (http://www.google.com.br) and Yahoo (http://www.yahoo.com.br). The search method used was the same method described in other studies that evaluated the quality of health information on the websites, with the selection of the most popular and commonly used search engines, according to Alexa data (www.alexa.com) (Alexa, 2019; Cajita et al., 2017; Weymann et al., 2014).

At Google, the "Advanced Search" mode was used, with the application of the language filters "pages in Portuguese" and the "Brazil" region. At Yahoo, the standard search mode was chosen, selecting the filter "In Portuguese (Brazil)". The search for the electronic websites was performed on the same date and time, on a computer in the institution's computer lab where the study was carried out, whose browser was previously configured to clean the navigation data. This procedure was carried out to minimize the possible influence of personalized search results due to invisible filters present in the search websites.

Two searches were performed on each search engine with the following combinations of words and Boolean operators: "pain" AND (drugs OR remedies OR analgesics) and "pain treatment". The searches were carried out only in thePortuguese language of Brazil, as the study aimed to analyze national websites.

The first 200 Uniform Resource Locator (URL) obtained in each search were compiled in a Microsoft Office Excel spreadsheet, numbered in sequential order, and distributed in alphabetical order. The excluded URLs were: duplicate URLs; those that redirected to files in ".pdf" (Adobe Acrobat) and ".doc" or ".docx" (Microsoft Office Word) formats; inaccessible or inoperative links; blogs; pages corresponding to articles and scientific journals; newspaper or magazine articles or news; links to pharmacies and drugstores, exclusively for sale medicines; and links whose content did not address the pharmacological treatment of pain.

The instruments for assessing the quality of global information and specific content on analgesic drugs were applied to each selected website. The scoring reference established by Charnock et al. (1999) in the DISCERN questionnaire was used to website's level quality. It is considered a three-point descriptive scale, similar to that carried out in other studies (Gupta et al., 2017; Yeung \& D’Souza, 2013). For each sentence, the presence or absence of the evaluated criterion on the websites selected was verified, with up to three possibilities of answers linked to a given score: absence - one (1); partial presence - two (2) or total presence - three (3).

The final score, obtained by the sum of all sentences evaluated, was converted into a percentage, allowing the pages to be categorized into three levels of quality: high, moderate, and low. The high quality occurred if the final score value was equal to or greater than $80 \%$ of the maximum score, so the website was considered a valuable and adequate source of information. Final score values between 50 and $79 \%$ indicated moderate quality, being the publication considered a source of 
information with reservations, limitations, and the need for additional data. And the final score values below $50 \%$ of the maximum score showed low quality, indicating that the website had severe deficiencies in the content, not a valuable and adequate source of information (Charnock et al., 1999; Ramos et al., 2020).

The URLs were divided into five categories: government, drugstore, pharmaceutical industry, health professional, and "others". Also, URLs that mentioned dipyrone, acetaminophen, NSAIDs, opioids, and adjuvants were quantified. On each page of the website, the presence or absence of drug advertising was also verified.

The results were shown through frequency distribution (absolute and relative percentage) and calculating central tendency measures (mean) and dispersion (standard deviation).

\section{Results}

The tool developed by Mendonça and Pereira Neto (2015) consists of 80 sentences, divided between content (18), technical (40), and design (22) dimensions, which establish minimum quality criteria and indicators for online health information. Mainly sentences related to the navigation profile and layout of the website were excluded from the original tool because those questions did not fall within the study's scope. The final tool totaled 32 sentences were distributed in two dimensions: 10 in content and 22 in technical.

Figure 1 was structured to present the search flow and apply the exclusion criteria to websites obtained from Google and Yahoo search engines. The search for websites with the terms "pain" AND (drugs OR remedies OR analgesics) returned approximately 32,600 results on Google and 4,820 on Yahoo. In comparison, the words "pain treatment" retrieved about 31,600 and 22,000 results on Google and Yahoo, respectively. From the 800 selected URLs, after applying all the exclusion criteria, a total of 98 URLs were obtained for analysis. 
Figure 1. Flow of collection and application of exclusion criteria to websites obtained from Google and Yahoo search engines, Brazil, 2019.

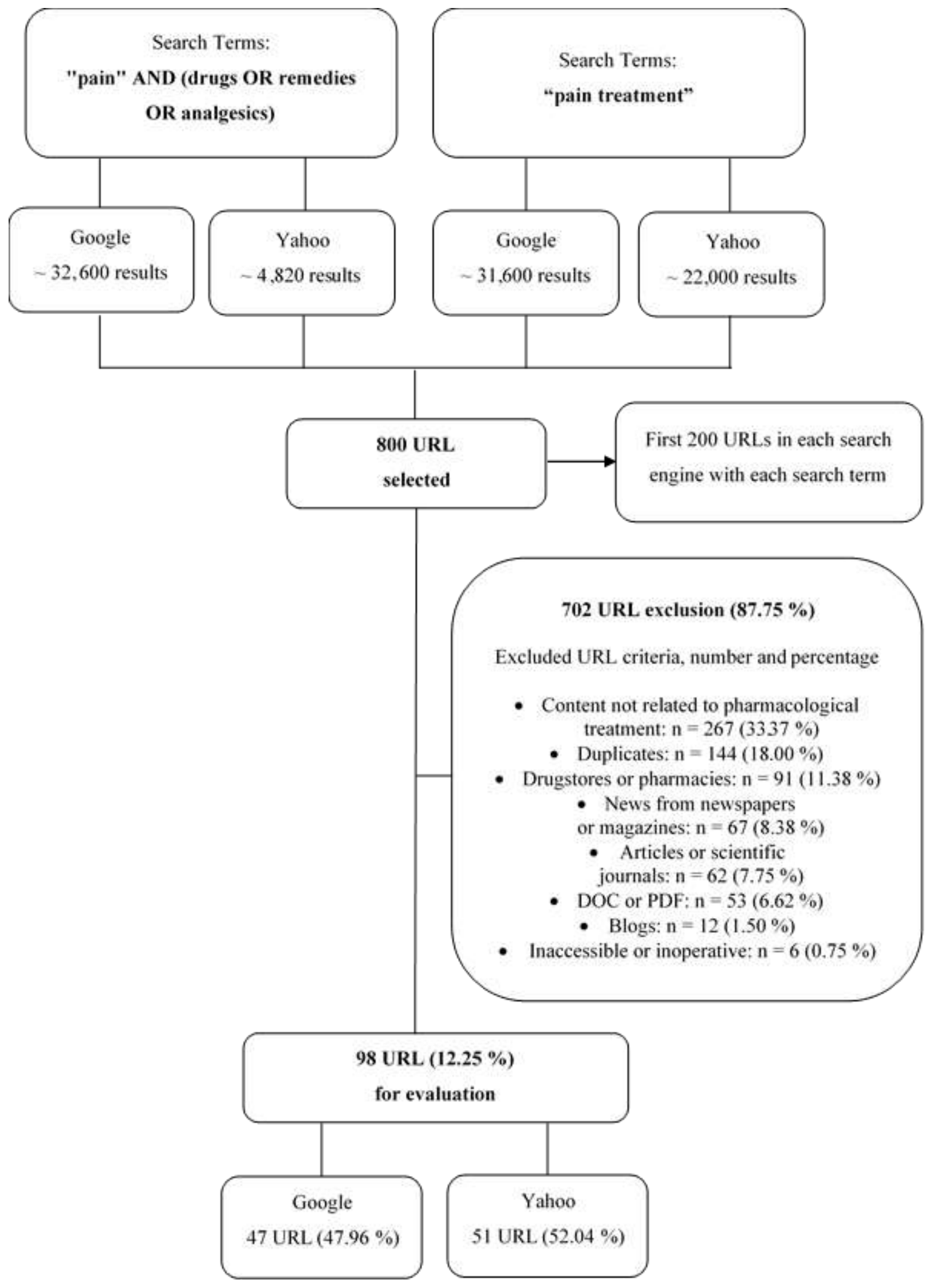

Source: Authors.

The characterization of the profile of the websites evaluated was shown in Table 1. The class of nonsteroidal anti- 
inflammatory drugs was the most mentioned (83.67\%), followed by acetaminophen (59.18 \%). Regarding the affiliation of the person responsible for the website, most of them belonged to the category "Others" (73.47\%), including non-governmental organizations (NGOs) websites, health information portals, and electronic health magazines.

Table 1. Characterization of the profile of the websites evaluated according to the type of analgesic, drug mentioned and the affiliation, $\mathrm{n}=98$, Brazil, 2019.

\begin{tabular}{lc}
\hline \multicolumn{1}{c}{ Characteristics } & $\mathbf{n}(\boldsymbol{\%})$ \\
\hline Analgesic & $82(83.67)$ \\
NSAIDs & $58(59.18)$ \\
Acetaminophen & $47(47.96)$ \\
Opioids & $38(38.78)$ \\
Dipyrone & $32(32.65)$ \\
Antidepressants & $28(28.57)$ \\
Anticonvulsants & \\
Affiliation & $72(73.47)$ \\
Others & $13(13.27)$ \\
Health Professional & $8(61.54)$ \\
\multicolumn{1}{c}{ Doctor } & $4(30.77)$ \\
$\quad$ Physiotherapist & $1(7.69)$ \\
Nurse & $11(11.22)$ \\
Pharmaceutical Industry & $1(1.02)$ \\
Drugstore & $1(1.02)$ \\
Government &
\end{tabular}

Source: Authors.

Table 2 presented the analysis of the websites related to the content dimension criteria according to the global health information quality assessment tool. We observed that $42.86 \%$ of the websites mentioned diagnostic information and all described pharmacological treatment options for pain. The benefits and performance of treatments and products were mentioned in $60.20 \%$ of the pages; however, only $35.71 \%$ contained information about possible drug complications. Despite the information on treatment possibilities on all pages, the content was scientifically documented only in $34.69 \%$, presenting the sources that supported the available information. However, only $28.57 \%$ of the websites had widely recognized origins and a good reputation (scientific articles, guidelines from scientific societies). 
Table 2. Analysis of the websites related to the content dimension criteria according to the global health information quality assessment tool, $\mathrm{n}=98$, Brazil, 2019.

\begin{tabular}{|c|c|c|}
\hline \multirow{2}{*}{ Indicator - Content Dimension } & \multicolumn{2}{|c|}{ n $(\%)$} \\
\hline & Yes & No \\
\hline 1. Is there any information on diagnosis? & $42(42.86)$ & $56(57.14)$ \\
\hline 2. Is there any information on treatment? & $98(100.0)$ & $0(0)$ \\
\hline 3. Is there any information on the side effects of the treatment? & $35(35.71)$ & $63(64.29)$ \\
\hline 4. Is there any information on the benefits and performance of the treatments? & $59(60.20)$ & $39(39.80)$ \\
\hline $\begin{array}{l}\text { 5. Is there any contact on where to look for more information about the diagnosis, treatment } \\
\text { and prevention? }\end{array}$ & $14(14.29)$ & $84(85.71)$ \\
\hline $\begin{array}{l}\text { 6. Is the content by the current stage of scientific knowledge (studies, researches, protocols, } \\
\text { consensus, or clinical practice)? }\end{array}$ & $34(34.69)$ & $64(65.31)$ \\
\hline 7. Is the information sources available? & $34(34.69)$ & $64(65.31)$ \\
\hline 8. Are the sources widely recognized and reputable? & $28(28.57)$ & $70(71.43)$ \\
\hline 9. Is the language appropriate for the target public? & $87(88.78)$ & $11(11.22)$ \\
\hline 10. Is there technical words or jargon unknown to the general public? & $19(19.39)$ & $79(80.61)$ \\
\hline
\end{tabular}

Source: Authors.

When analyzing the websites with the 22 questions related to the technical dimension criteria, as shown in Table 3, we observed that just under half of the websites indicated the authors of the information (45.92\%); however, approximately onethird contained the identification credentials $(33.67 \%)$. The information on dates creation and updating of the pages were present in $22.45 \%$ and $47.96 \%$, respectively. The advertisements were identified in $64.29 \%$ of the websites, but only $7.14 \%$ were associated with drug advertising. Only $35.71 \%$ of the websites indicated that qualified professionals provided health advice. Despite this, $73.47 \%$ of them reported the need for medical consultation and evaluation.

Table 3. Analysis of the websites related to the technical dimension criteria according to the global health information quality assessment tool, $\mathrm{n}=98$, Brazil, 2019.

\begin{tabular}{lrc}
\hline \multicolumn{1}{c}{ Indicator - Technical Dimension } & n (\%) & Yes \\
\cline { 2 - 3 } & No \\
\hline 1. Is there the author of the information? & $45(45.92)$ & $53(54.08)$ \\
2. Were the authors' credentials provided? & $33(33.67)$ & $65(66.33)$ \\
3. Does the website provide the author's contact addresses? & $14(14.29)$ & $84(85.71)$ \\
4. Does the website inform who the responsible person is? & $11(11.22)$ & $87(88.78)$ \\
5. Do you have information about the person in charge? & $5(5.10)$ & $93(94.90)$ \\
6. Is the date of the establishment of the website available? & $22(22.45)$ & $76(77.55)$ \\
7. Is the date of the last update available? & $47(47.96)$ & $51(52.04)$ \\
\hline
\end{tabular}

Source: Authors. 
Table 4. Analysis of the websites related to the technical dimension criteria according to the global health information quality assessment tool, $\mathrm{n}=98$, Brazil, 2019 (Continued).

\begin{tabular}{|c|c|c|}
\hline \multirow{2}{*}{ Indicator - Technical Dimension } & \multicolumn{2}{|c|}{ n (\%) } \\
\hline & Yes & No \\
\hline 8. Does the creation date of the content appear? & $44(44.90)$ & $54(55.10)$ \\
\hline 9. Does the updated date appear on all pages/content on the website? & $47(47.96)$ & $51(52.04)$ \\
\hline 10. Is the purpose of the website presented? & $53(54.08)$ & $45(45.92)$ \\
\hline 11. Is the aim of the website clear? & $56(57.14)$ & $42(42.86)$ \\
\hline 12. Does the website mention the audience for which the information is intended? & $21(21.43)$ & $77(78.57)$ \\
\hline 13. Is financial support and partnership mentioned? & $32(32.65)$ & $66(67.35)$ \\
\hline 14. Has the website been certified by an accrediting institution? & $5(5.10)$ & $93(94.90)$ \\
\hline 15. Does the website have any commercial advertisements identified? & $63(64.29)$ & $35(35.71)$ \\
\hline 16. Is there a distinction between ads and content? & $32(32.65)$ & $66(67.35)$ \\
\hline 17. Are health advice provided by qualified professionals? & $35(35.71)$ & $63(64.29)$ \\
\hline 18. Does the website notify the need for medical consultation? & $72(73.47)$ & $26(26.53)$ \\
\hline 19. Is there interactive tools (forum, blog, chat, social networks, or comments)? & $30(30.61)$ & $68(69.39)$ \\
\hline 20. Does the website offer FAQ (Frequently Asked Questions) to users? & $7(7.14)$ & $91(92.86)$ \\
\hline 21. Does the website offer user help tutorials? & $1(1.02)$ & $97(98.98)$ \\
\hline 22. Is there a contact us section on the website? & $68(69.39)$ & $30(30.61)$ \\
\hline
\end{tabular}

Source: Authors.

The pharmacological content about analgesic drugs on websites was represented in Table 5. It was observed that all evaluated websites describe the treatment for some type of pain, even if partial, in which it was the majority (71.43 \%). Few characterize the type of pain and its relationship with the treatment $(15.31 \%)$, and the lower frequency of the websites correlated the pain intensity and the treatment $(5.19 \%)$. It is noteworthy that only $7.14 \%$ of the websites reported on the treatment time.

When analyzing the main adverse effects, most of the websites did not mention it, regardless of the type of analgesic cited (dipyrone $93.88 \%$; acetaminophen $80.61 \%$; NSAIDs $75.51 \%$; opioids $72.45 \%$ and adjuvants - anticonvulsants and antidepressants - $92.86 \%$ ). The information about analgesic drugs contraindications was highly reduced and incomplete (see Table 5).

Regarding websites that referred to the use of opioids, only $18.37 \%$ mentioned tolerance effects and dependence, and $8.16 \%$ about the risks of abrupt discontinuation. Very few websites inform guidelines related to management in accidental cases of intoxication $(4.08 \%)$. No website provided complete information on the non-pharmacological treatment of pain or complementary, integrative practices, such as acupuncture (see Table 5). 
Table 5. Analysis of the websites related to the pharmacological dimension criteria according to the tool for assessing the quality of information on analgesic drugs, $\mathrm{n}=98$, Brazil, 2019.

\begin{tabular}{|c|c|c|c|}
\hline \multirow{2}{*}{ Indicator - Pharmacological Dimension } & \multicolumn{3}{|c|}{ n (\%) } \\
\hline & Yes & Partial & No \\
\hline 1. Describes the definition of pain? & $23(23.47)$ & N/A & $75(76.53)$ \\
\hline 2. Describes the types of pain? & $13(13.27)$ & $4(4.08)$ & $81(82.65)$ \\
\hline $\begin{array}{l}\text { 3. Is there information that pain is a symptom associated with some dysfunction in the } \\
\text { body? }\end{array}$ & $45(45.92)$ & N/A & $53(54.08)$ \\
\hline 4. Describe pharmacological treatment options? & $28(28.57) 7$ & $70(71.43)$ & $0(0)$ \\
\hline $\begin{array}{l}\text { 5. Does the website describe the pharmacological treatment recommended according to } \\
\text { the type of pain? }\end{array}$ & $15(15.31)$ & $8(8.16)$ & $75(76.53)$ \\
\hline $\begin{array}{l}\text { 6. Does the website describe the pharmacological treatment recommended according to } \\
\text { the intensity of pain? }\end{array}$ & $5(5.10)$ & $19(19.39)$ & $74(75.51)$ \\
\hline $\begin{array}{l}\text { 7. Is there a differentiation of the types of analgesics according to the pharmacological } \\
\text { treatment? }\end{array}$ & $55(56.12)$ & N/A & $43(43.88)$ \\
\hline 8. Is there a differentiation of the types of analgesics according to the treatment time? & $7(7.14)$ & N/A & $91(92.86)$ \\
\hline $\begin{array}{l}\text { 9. Does the website describe the main adverse reactions associated with the use of } \\
\text { analgesic drugs? }\end{array}$ & & & \\
\hline Dipyrone & $0(0)$ & $6(6.12)$ & $92(93.88)$ \\
\hline Acetaminophen & $1(1.02)$ & $18(18.37)$ & $79(80.61)$ \\
\hline NSAIDs & $8(8.16)$ & $16(16.33)$ & $74(75.51)$ \\
\hline Opioids & $15(15.31)$ & $12(12.24)$ & $71(72.45)$ \\
\hline Anticonvulsants & $1(1.02)$ & $6(6.12)$ & $91(92.86)$ \\
\hline Antidepressants & $3(3.06)$ & $4(4.08)$ & $91(92.86)$ \\
\hline
\end{tabular}

10. Does the website describe the main contraindications to the use of analgesic drugs?

\begin{tabular}{|c|c|c|c|}
\hline Dipyrone & $0(0)$ & $0(0)$ & $98(100.0)$ \\
\hline Acetaminophen & $0(0)$ & $3(3.06)$ & $95(96.94)$ \\
\hline NSAIDs & $2(2.04)$ & $6(6.12)$ & $90(91.84)$ \\
\hline Opioids & $0(0)$ & $2(2.04)$ & $96(97.96)$ \\
\hline Anticonvulsants & $0(0)$ & $0(0)$ & $98(100.0)$ \\
\hline Antidepressants & $0(0)$ & $0(0)$ & $98(100.0)$ \\
\hline $\begin{array}{l}\text { Is there risks associated with the continued use of painkillers for an extended } \\
\text { od? }\end{array}$ & $11(11.22)$ & N/A & $87(88.78)$ \\
\hline $\begin{array}{l}\text { Is there the risk of dependence and tolerance associated with continuous use of } \\
\text { Igesic drugs in the case of opioids? }\end{array}$ & $18(18.37)$ & N/A & $80(81.63)$ \\
\hline Are there any risks of abrupt discontinuation related to opioids painkillers? & $8(8.16)$ & N/A & $90(91.84)$ \\
\hline
\end{tabular}


Table 6. Analysis of the websites related to the pharmacological dimension criteria according to the tool for assessing the quality of information on analgesic drugs, $\mathrm{n}=98$, Brazil, 2019 (Continued).

\begin{tabular}{lrrr}
\hline \multicolumn{1}{c}{ Indicator - Pharmacological Dimension } & \multicolumn{2}{c}{$\mathbf{n}(\%)$} \\
\cline { 2 - 4 } & Yes & Partial & No \\
\hline $\begin{array}{l}\text { 14. Does the website mention whether or not there is a need for a medical prescription } \\
\text { to purchase painkillers? }\end{array}$ & $23(23.47)$ & N/A & $75(76.53)$ \\
15. Does the website describe special use of painkillers in certain age groups? & $0(0)$ & $10(10.20) 88(89.80)$ \\
16. Is there information on the use of herbal medicines concomitantly with painkillers? \\
$\begin{array}{l}\text { 17. Is there information on the use of alcoholic beverages concomitantly with } \\
\text { painkillers? }\end{array}$ & $9(0)$ & $0(0)$ & $98(100.0)$ \\
18. Is there information on the use of tobacco concomitantly with painkillers? & $0(0)$ & $89(90.82)$ \\
19. Does the website mention guidelines for the user related to handling accidental cases \\
of high doses, intoxications? \\
$\begin{array}{l}\text { 20. Are there non-pharmacological treatment options and integrative and } \\
\text { complementary health practices (acupuncture, meditation, aromatherapy, }\end{array}$
\end{tabular}

Legend: N/A - Not Apply. Source: Authors.

Table 7 summarized the quality level of information from Brazilian websites on analgesic drugs evaluated. The data pointed that there was a predominance of pages with moderate quality in the content and technical dimensions, corresponding to $73.47 \%$ and $61.22 \%$, respectively. On the other hand, in the pharmacological dimension, the results indicated a prevalence of low-quality level $(85.71 \%)$. The final general classification in information quality levels was carried out in two ways: the first considering the sum of the scores of the three dimensions, and the second disregarding the pharmacological dimension. None of the 98 websites evaluated had a high level of quality to be considered an adequate source of information in both cases. Most of them were classified at a moderate level, representing $54.08 \%$ in the first case and $84.69 \%$ in the second case (see Table 7).

Certification by an accrediting institution was observed, characterized by the presence of the HONcode seal, in only $32.65 \%$, all of which are allocated at a moderate quality level, considering the final general classification obtained in a second way. Most of the certified electronic websites corresponded to the "others" $(87.5 \%)$, followed by the pharmaceutical industry $(9.38 \%)$ and health professionals ( $3.57 \%)$. Regarding websites position occupied in the results obtained in the search engines, a balanced distribution was observed between the first and last positions of the search. $53.12 \%$ of them were found in the range of positions 1 to 50 .

When analyzing the level of quality of information on the websites, considering the distribution by type of analgesic medication mentioned on the website, it was observed that there was a prevalence of moderate quality for all types: dipyrone (55.26\%); acetaminophen (62.07\%); NSAID (56.10\%); opioids (72.34\%); antidepressants $(62.50 \%)$ and anticonvulsants $(67.86 \%)$. 
Table 7. Quality level of information from Brazilian websites on analgesic drugs, $n=98$, Brazil, 2019.

\begin{tabular}{|c|c|c|c|c|c|}
\hline \multirow[b]{2}{*}{$\begin{array}{c}\text { Quality } \\
\text { Level }\end{array}$} & \multirow[b]{2}{*}{$\begin{array}{c}\text { Content } \\
\text { Dimension } \\
\text { n (\%) }\end{array}$} & \multirow[b]{2}{*}{$\begin{array}{c}\text { Technical } \\
\text { Dimension } \\
\text { n }(\%)\end{array}$} & \multirow[b]{2}{*}{$\begin{array}{c}\text { Pharmacological } \\
\text { Dimension } \\
\text { n }(\%)\end{array}$} & \multicolumn{2}{|c|}{ Final Classification } \\
\hline & & & & $\begin{array}{c}\text { Two } \\
\text { Dimensions } \\
\text { n }(\%)\end{array}$ & $\begin{array}{c}\text { Three } \\
\text { Dimensions } \\
\text { n (\%) }\end{array}$ \\
\hline Low & $10(10.20)$ & $38(38.78)$ & $84(85.71)$ & $15(15.31)$ & $45(45.92)$ \\
\hline Moderate & $72(73.47)$ & $60(61.22)$ & $14(14.29)$ & $83(84.69)$ & $53(54.08)$ \\
\hline High & $16(16.33)$ & $0(0)$ & $0(0)$ & $0(0)$ & $0(0)$ \\
\hline
\end{tabular}

Legend: Quality level: Low - Below 50\% of the total score; Moderate - Between 50 and $79 \%$ of the total score; High - Above $80 \%$ of the total score. Source: Authors.

\section{Discussion}

The data from the present study showed that more than half of the websites evaluated (54.08\%) had a moderate level of information quality, including those that had the HONcode certification. This means that they are fair sources of information about analgesic drugs, with important limitations and restrictions on their content, in addition to the need for extra information to supplement. The results agree with those of Kaicker et al. (2010), who studied 161 websites about pain management in the English language.

The absence of complete information about diseases and treatments can contribute to the incorrect use of drugs, placing patients' health at risk (Gondim et al., 2012). With the present results, the importance of evaluating and knowing the quality of the information conveyed on the Internet and accessed by individuals is emphasized, in an attempt to define quality standards, guaranteeing more excellent safety to users (Moretti et al., 2012; Ramos et al., 2020). The literature on the evaluation of the quality of information on medicines on the Internet is minimal.

The tool developed by Mendonça and Pereira Neto (2015) was chosen as the basis for use in this work due to three main factors: more recent study; inclusion of the criteria and indicators addressed by the methodologies most used in the evaluation of information quality (references from DISCERN, JAMA, and HONcode); and it was developed based on the assessment of Brazilian websites

Several types of analgesic drugs have been mentioned on the websites. Still, the NSAID class highlights, which are among the most prescribed and consumed drugs worldwide, are indisputable. There is a wide range of different medications included in the class, with analgesic, antipyretic and anti-inflammatory properties, allowing their indication in treating various disorders involving pain, fever, and inflammation (Pedroso \& Batista, 2017). Also, some nonsteroidal anti-inflammatory drugs and acetaminophen do not need a prescription for sale in several countries, including Brazil. In Brazil, unlike many European countries and the United States, dipyrone is commercialized, which has a significant analgesic and antipyretic effect. There is also no need for a medical prescription for its purchase. These drugs are easily found in pharmacies and drugstores, which can favor their acquisition and spread the use (Arrais et al., 2016; Pedroso \& Batista, 2017). 
On the other hand, the group of opioids and adjuvants, represented here by antidepressants and anticonvulsants, were the least mentioned. These classes include drugs subject to special control, requiring a medical prescription for retention at the time of purchase. Besides, these drugs are generally used in more restricted conditions, such as cases of acute pain of greater intensity, cancer pain, pain refractory to other treatments, among different situations that analgesia is wished (Cox, 2010; Horgas, 2017). Given this, it is noteworthy that few pages (23.47\%) reported on the requirement for a medical prescription for the purchase of drugs subject to special control, making it difficult for individuals to understand the specific conditions for the purchase of each type of painkiller.

Just over a third of the websites $(35.71 \%)$ mentioned possible complications in the treatment, while information on benefits and performance were present in just over half of them (60.20\%). Although advertising associated with medicines was present on a few pages $(7.14 \%)$ and the majority $(73.47 \%)$ indicated that medical consultation is essential, the increasing number of content provided in the virtual environment is alarming. Most advertisements follow publication techniques generally used in advertising and marketing in the media in general, disseminating information endowed with imbalance and bias (Arrais et al., 2016). The tactic of emphasizing benefits and minimizing possible treatment complications aligns with what is described in the literature (Cerminara et al., 2014; Ramos et al., 2020).

The disclosure of incomplete and inappropriate content is quite worrying, as people rely on this information for diagnosis and self-medication and may compromise their safety (Oliveira et al., 2013). This tends to confuse the minds of users, who may regard medicines as entirely safe and without any type of risk, influencing self-medication and exacerbated consumption (Arrais et al., 2016). The inadequate information present on the websites can induce the individual to use unnecessary products or inappropriate to their condition, collaborating for the irrational use of drugs, with risks of developing severe damage to health (Gondim et al., 2012; Moretti et al., 2012; Pereira Neto et al., 2013). The problem can be facilitated by the wide availability of places on the Internet intended for the sale of medicines, often at more accessible prices and without the need for a medical prescription (Pereira Neto et al., 2016), including for drugs subject to special control (UNODC, 2019).

Although analgesics have many benefits, their use is also associated with several adverse effects, which can cause harm to users, with wide diversity in the type and severity of the reaction, depending on the class used (Farrar et al., 2017; Pedroso \& Batista, 2017). Also, they are listed among the main groups of drugs associated with cases of intoxication registered in Brazil and other countries (Rangel \& Francelino, 2018; Sandilands \& Bateman, 2016; Schaper \& Ebbecke, 2017). Therefore, the main adverse effects and contraindications must be cited on the websites that report on analgesic drugs; this was not observed in the present study.

Most of the evaluated websites did not indicate the references used, the authors of the content, or dates of creating and updating the publications. This reflects in the low reliability and credibility of the electronic websites and the information conveyed. The results are in line with what was reported by Marcinkow et al. (2019), which assessed the quality of data on the Internet about contraceptive drugs.

In this study, websites about osteoarthritis and its treatment were evaluated in ten countries, including Brazil. Among the pages classified as low quality, none had the HON certification, in line with what was described in the study by Varady et al. (2018). They identified that websites with the HONcode seal had higher levels of quality and reliability than those that did not have this certification, as expected.

The established codes of conduct and quality standards, such as HONcode, were created to standardize the minimum criteria required for health publications on the Internet. These aim to ensure that the content published is correct, appropriate, impartial, and follows ethical principles necessary for the safety of users who will come into contact with the information (Boyer et al., 2017). Those responsible for websites' greater involvement and commitment to see certification as an advantage are emphasized in this context. They seek to provide content with greater credibility and reliability to the general public 
(Kaicker et al., 2010; Ramos et al., 2020).

The HONcode seal was detected on electronic websites with different positions in the results returned by the search engines, from the first to the last places, the majority of which are classified with a moderate quality level. These results reinforce what was pointed out by Joury et al. (2016), who evaluated American websites about symptoms of chest pain and detected pages with the highest score in the JAMA benchmarks criteria placed in distant positions from the first in the search engine ranking. The authors indicated no correlation between the ranks of the links in the search engine results and the quality of the information. In contrast, Bailey et al. (2013) evaluated American websites about chronic pain, comparing the scores and levels of quality obtained among the 50 selected websites, and found a better classification in those that occupied the top ten positions in the search results.

The classification of results in search engine searches is based on complex algorithms whose adopted mechanism is not well-publicized. It is believed that the position of electronic websites in the ranking is mainly associated with user traffic, involving the number of visitors and page popularity, and not with their information quality (Arif \& Ghezzi, 2018; Gupta et al., 2017; Yeung \& D'Souza, 2013). This tends to influence lay users always to access the first pages, considering popularity over quality. This fact can contribute to the difficulty of people in identifying which of the pages accessed can be deemed adequate and safe sources of information (Gupta et al., 2017; Yeung \& D'Souza, 2013).

Although the keywords are closely related to analgesics, less than $1 / 4$ of the pages presented the definition of pain $(23.47 \%)$ and a description of the type of pain (13.27\%) (acute and chronic), considering its duration. Besides, just under half of the pages $(45.92 \%)$ pointed out that pain represents a symptom associated with some dysfunction in the body. The low percentages found indicate important fragility in the information published on the internet pages. These should make individuals aware of the importance of seeking medical attention to detect pain early, its origin, and type to ensure better pain control (Savvas \& Gibson, 2016). In general, pain is overlooked by individuals, being classified as a minor disorder and considered a common symptom of low severity. This thought can induce people not to seek medical attention and wait for the symptom to disappear independently, with the risk of worsening the condition. On the other hand, especially in acute pain conditions, the view of pain as something simple is capable of leading individuals to practice self-medication, aiming at a quick resolution of the problem, with the Internet being used with high frequency to consult this information (Pegoraro et al., 2019).

More than $2 / 3$ of the evaluated pages $(71.43 \%)$ cited one to three types of painkillers, and few $(18.37 \%)$ addressed non-pharmacological treatment options. However, it is noteworthy that most of them did not mention the main adverse reactions nor the contraindications for use. Besides, very few pages (11.22\%) warned of the risks associated with the continued use of painkillers. In general, treatment with acetaminophen and NSAIDs is considered safe for most patients, as long as they are used correctly and appropriately (Horgas, 2017). Despite this, the risks of toxicity and associated adverse effects should not be disregarded. The most common adverse effects are gastrointestinal tract irritations, changes in hemostasis, renal and hepatic dysfunction (Farrar et al., 2017; Pedroso \& Batista, 2017), in addition to hypersensitivity reactions (Aun et al., 2014).

The class of opioids is known mainly for the risks of dependence and tolerance associated with its use (Manchikanti et al., 2010). The epidemic of overdose deaths, especially in the USA, consists of a severe public health problem worldwide, resulting from the prescription and abuse of these substances (Wilkerson et al., 2016). In this context, it is alarming that few pages $(18.37 \%$ ) addressed this type of complication and only $8.16 \%$ indicated the risk of abrupt discontinuation of treatment, which can cause withdrawal syndrome.

In this context, the need to evaluate the content of drugs published on the Internet is reinforced since they do not emphasize the possible complications resulting from the treatment. It is believed that knowing the principal risks and adverse 
effects of pharmacological therapy is essential for the population to have more control and responsibility in the use of medicines and the reduction of possible damage to health.

The absence of important information on drug use in groups is more susceptible to drug-related problems, such as pediatric and elderly patients. These groups present distinct and variable body composition, physiological changes in metabolism, renal and liver function, and also variations in pharmacokinetic parameters. Even with doses considered standard for most individuals, the therapeutic effects can be exacerbated with a greater chance of adverse effects and toxicity in these age groups (Johnson et al., 2019).

The awareness of users about the risks and the guidelines regarding actions taken when misusing analgesic drugs is also essential information. It is believed that this can stimulate individuals to seek emergency medical care, assisting in early detection and faster resolution of poisoning cases (Rangel \& Francelino, 2018; Sandilands \& Bateman, 2016; Schaper \& Ebbecke, 2017).

Non-pharmacological treatment with complementary, integrative practices, such as acupuncture, has good results in pain relief (Dacal \& Silva, 2018). Despite this, none of the websites had this information.

The general analysis of the data, considering only the dimensions of global health assessment (content and technical), indicated that most of the pages $(84.69 \%)$ met more than half of the quality criteria established in the methodology, being classified with a level of moderate quality. The data pointed out some important deficiencies, mainly from the content and technical dimensions, related to the lack of information on accuracy, credibility, reliability, and security of publications. A similar trend was observed by Connelly et al. (2018) that indicated that the average score achieved was equivalent to just over $50 \%$ of the overall score of the evaluated quality criteria, on websites with information on diverticulitis, in Ireland.

Bailey et al. (2013) recorded a different result when evaluating websites about chronic pain in English. The DISCERN tool was used to analyze 408 websites, and only $13 \%$ were classified as high quality, remaining in most of the low-quality levels, with severe deficiencies in the information provided.

Ramos et al. (2020) started from the same global information assessment tool used in this study and obtained a worse result when analyzing information on benzodiazepines. The analysis showed that $56.3 \%$ of the evaluated websites were classified as disabled or very deficient. The authors reinforced that the low quality of information conveyed on the Internet can increase the irrational use of drugs, compromising the safety of individuals due to the risks of adverse effects resulting from erroneous therapy.

It should be noted that when the pharmacological dimension was included in the result of the general evaluation, the website's classification changed. The distribution was more balanced between the moderate and low levels, with a slight predominance of moderate quality (54.08\%). The result was even better than that presented by Silva et al. (2010), who found about two-thirds of the evaluated websites without most of the criteria present in the instruments considered essential information for individuals about the pharmacological treatment of obesity. According to the authors, the incompleteness and inaccuracy of the content can be harmful since they can induce individuals to make certain decisions, with the inappropriate use of drugs interfering with the expected therapy results.

The increase in the number of pages allocated at a low-quality level in the final classification, considering the pharmacological dimension, is based on the absence of information listed as a minimum and essential component for publications that propose to address the topic of analgesics. These mainly involve information about adverse reactions, contraindications, treatment time, risks associated with continuous use, need for a prescription, concomitant use of alcohol, and tobacco.

Among the main limitations of the present study, the dynamic nature of the Internet stands out, which allows constant and continuous modifications in the contents published. In evaluating global dimensions, the tool developed by Mendonça and 
Pereira Neto (2015) was adapted, removing original sentences from content and technical dimensions and omitting the design dimension. Therefore, the analysis did not include all criteria and indicators described as necessary for assessing the quality of information on the Internet. Another limitation would be the keywords chosen to search the websites. Although they represent general and straightforward terms, it isn't easy to assume which expressions users can use in a typical internet search. Thus, the analysis performed covered the possible set of pages on the topic obtained as results in a search.

\section{Conclusion}

The predominance of moderate to low quality on the selected websites indicates that, in general, the content on pain and analgesic drugs published on Brazilian websites is unsatisfactory, not meeting the quality standards that would be expected from a source of health information. Thus, there is a need to alert to the possible impact that the information conveyed may cause, especially for the lay population on the topic. The scenario shown reinforces the need for urgency in the analysis and regulation of content available on the Internet that addresses health and the use of drugs. It is suggested that further studies on this theme be carried out, aiming to expand the global discussion and draw the attention of official and regulatory bodies in health and the providers and representatives of this means of communication. Initiatives must ensure that society has access to reliable, safe, and adequate information on health, illness, monitoring, management, and treatment, to avoid the irrational use of drugs and the severe problems resulting from misuse.

\section{Acknowledgments}

The authors thank the Federal Fluminense University (UFF) and the program of professional master (GAFAR).

\section{References}

Alexa. The top 500 websites on the web (2019). https://www.alexa.com/topwebsites/category/Top/Computers/Internet/ Searching/Search_Engine

Arif, N. \& Ghezzi, P. (2018). Quality of online information on breast cancer treatment options. The Breast, 37, 6-12. https://doi.org/10.1016/j.breast.2017.10.004

Arrais, P. S. D., Fernandes, M. E. P., Dal Pizzol, T. S., Ramos, L. R., Mengue, S. S., Luiza, V. L., Tavares, N. U. L, Farias, M. R., Oliveira M. A. \& Bertoldi, A. D. (2016). Prevalência da automedicação no Brasil e fatores associados. Revista de Saúde Pública, 50(Supl. 2), S1-S11. https://doi.org/10.1590/s15188787.2016050006117

Aun, M. V., Blanca, M., Garro, L. S., Ribeiro, M. R., Kalil, J., Motta, A. A., Castells, M. \& Giavina-Bianchi, P. (2014). Nonsteroidal Anti-Inflammatory Drugs are Major Causes of Drug-Induced Anaphylaxis. The Journal of Allergy and Clinical Immunology: In Practice, 2(4), 414-420. https://doi.org/10.1016/j.jaip.2014.03.014

Bailey, S. J., LaChapelle, D. L., LeFort, S. M., Gordon, A. \& Hadjistavropoulo, T. (2013). Evaluation of Chronic Pain-Related Information Available to Consumers on the Internet. Pain Medicine, 14(6), 855-864. https://doi.org/10.1111/pme.12087

Boyer, C., Frossard, C., Gaudinat, A., Hanbury, A. \& Falquetd, G. (2017). How to sort trustworthy health online information? Improvements of the automated detection of HONcode criteria. Procedia Computer Science, 121, 940-949. https://doi.org/10.1016/j.procs.2017.11.122

Cajita, M.I., Rodney, T., Xu, J., Hladek, M. \& Han, H. (2017). Quality and Health Literacy Demand of Online Heart Failure Information. Journal of Cardiovascular Nursing, 32(2), 156-164. https://doi.org/10.1097/JCN.0000000000000324

Cerminara, C., Santarone, M. E., Casarelli, L., Curatolo, P. \& El Malhany, N. (2014). Use of the DISCERN tool for evaluating web searches in childhood epilepsy. Epilepsy \& Behavior, 41, 119-121. https://doi.org/10.1016/j.yebeh.2014.09.053

Comitê Gestor da Internet no Brasil (2019). Pesquisa sobre o uso das tecnologias de informação e comunicação nos domicílios brasileiros : TIC domicílios 2018 = Survey on the use of information and communication technologies in brazilian households : ICT households 2018 [livro eletrônico]. Núcleo de Informação e Coordenação do Ponto BR. https://www.cetic.br/media/docs/publicacoes/2/12225320191028-tic_dom_2018_livro_eletronico.pdf

Charnock, D., Shepperd, S., Needham, G. \& Gann, R. (1999). DISCERN: an instrument for judging the quality of written consumer health information on treatment choices. Journal of Epidemiology and Community Health, 53(2), 105-111. http://dx.doi.org/10.1136/jech.53.2.105

Connelly, T. M., Khan, M. S., Victory, L., Mehmood, A. \& Cooke, F. (2018). An assessment of the quality and content of information on diverticulitis on the internet. The Surgeon, 16(6), 359-364. https://doi.org/10.1016/j.surge.2018.03.010 
Cox, F. (2010). Basic principles of pain management: assessment and intervention. Nursing Standard, 25(1), 36-39. 10.7748/ns2010.09.25.1.36.c7983

Dacal, M. P. O. \& Silva, I. S. (2018). Impactos das práticas integrativas e complementares na saúde de pacientes crônicos. Saúde Debate, 42(118), 724-735. https://doi.org/10.1590/0103-1104201811815

Farrar, F. C., White, D. \& Darnell, L. (2017). Pharmacologic Interventions for Pain Management. Critical Care Nursing Clinics of North America, 29(4), 427447. https://doi.org/10.1016/j.cnc.2017.08.004

Focosi, A. S. \& Souza, R. M. (2016). O mapa da dor crônica na internet: um estudo exploratório. Revista Dor, 17(2), 101-105. http://dx.doi.org/10.5935/18060013.20160024

Gondim, A. P. S., Weyne, D. P. \& Ferreira, B. S. P. (2012). Quality of health and medication information on Brazilian websites. Einstein, 10(3), 335-341. http://dx.doi.org/10.1590/S1679-45082012000300014

Gupta, A., Nissan, M. E., Bojrab II, D. I., Folbe, A. \& Carron, M. A. (2017). Do Patients Access Appropriate Information Online? Facial Plastic Surgery, 33(4), 428-433. https://doi.org/10.1055/s-0037-1603782

Horgas, A. L. (2017). Pain Assessment in Older Adults. Nursing Clinics of North America, 52(3), 375-385. https://doi.org/10.1016/j.cnur.2017.04.006

Instituto Brasileiro de Geografia e Estatística (2018). Pesquisa Nacional por Amostra de Domicílios Contínua: Acesso à Internet e à televisão e posse de telefone móvel celular para uso pessoal 2017. https://biblioteca.ibge.gov.br/visualizacao/livros/liv101631_informativo.pdf

Johnson, K. B., Bailey, T. \& Thackeray, E. (2019). Physiology and Pharmacology of Obesity, Pediatrics, and the Elderly. In J. R. Hemmings, C. Hugh, \& T. D. Egan (Eds.), Pharmacology and Physiology for Anesthesia: Foundations and Clinical Application (2nd ed., pp. 91-112). Elsevier. 10.1016/B978-0-32348110-6.00005-3

Joury, A. U., Alshathri, M., Alkhunaizi, M., Jaleesah, N. \& Pines, J. M. (2016). Internet Websites for Chest Pain Symptoms Demonstrate Highly Variable Content and Quality. Academic Emergency Medicine, 23(10), 1146-1152. https://doi.org/10.1111/acem.13039

Kaicker, J., Debono, V. B., Dang, W., Buckley, N. \& Thabane, L. (2010). Assessment of the quality and variability of health information on chronic pain websites using the DISCERN instrument. BMC Medicine, 8(59), 1-8. https://doi.org/10.1186/1741-7015-8-59

Manchikanti, L., Fellows, B., Ailinani, H. \& Pampati, V. (2010). Therapeutic Use, Abuse, and Nonmedical Use of Opioids: A Ten-Year Perspective. Pain Physician, 13(5), 401-435. https://www.painphysicianjournal.com/current/pdf?article=MTM4Mg\%3D\%3D\&journal=57

Marcinkow, A., Parkhomchik, P., Schmode, A. \& Yuksel, N. (2019). The Quality of Information on Combined Oral Contraceptives Available on the Internet. Journal of Obstetrics and Gynaecology Canada, 41(11), 1599-1607. https://doi.org/10.1016/j.jogc.2019.01.024

Mendonça, A. P. B. \& Pereira Neto, A. (2015). Critérios de avaliação da qualidade da informação em websites de saúde: uma proposta. Revista Eletrônica de Comunicação, Informação e Inovação em Saúde, 9(1), 1-15. https://doi.org/10.29397/reciis.v9i1.930

Moretti, F. A., Oliveira, V. E. \& Silva, E. M. K. (2012). Acesso a informações de saúde na internet: uma questão de saúde pública? Revista da Associação Médica Brasileira, 58(6), 650-658. http://dx.doi.org/10.1590/S0104-42302012000600008

Ng, L. \& Cashman, J. (2018). The management of acute pain. Medicine, 46(12), 780-785. https://doi.org/10.1016/j.mpmed.2018.09.009

Oliveira, F., Goloni-Bertollo, E. M. \& Pavarino, E. C. (2013). A Internet como fonte de Informação em Saúde. Journal of Health Informatics, 5(3), 98-102. http://www.jhi-sbis.saude.ws/ojs-jhi/index.php/jhi-sbis/article/view/267

Pedroso, C. R. \& Batista, F. L. (2017). O Uso Indiscriminado dos Antiinflamatórios Não Esteroidais. Saúde \& Ciência em Ação, 3(1), 48-69. https://revistas.unifan.edu.br/index.php/RevistaICS/article/view/332

Pegoraro, C. M. R., Bifaroni, R. M. S., Mareco, E. A., Tonizza, T. R. \& Silgueiro, L. I. (2019). Caracterização da prática de automedicação com analgésicos para o tratamento da dor. Colloquium Vitae, 11(3), 85-91. 10.5747/cv.2019.v11.n3.v274

Pereira Neto, A., Barbosa, L. \& Muci, S. (2016). Internet, geração Y e saúde: um estudo nas comunidades de Manguinhos (RJ). Comunidade \& Informação, 19(1), 20-36. https://doi.org/10.5216/ci.v19i1.35602

Pereira Neto, A. F., Santos, E. M., Cruz, M. M \& Torres, R. M. C. (2013). Avaliação de websites de saúde em questão: a Aids nos websites brasileiros de Organizações Não Governamentais (ONG) de Lésbicas, Gays, Bissexuais, Travestis e Transexuais (LGBT). Revista Eletrônica de Comunicação, Informação e Inovação em Saúde, 7(1), 1-20. 10.3395/reciis.v7i1.588pt

Ramos, T. B., Bokehi, L. C., Oliveira, E. B., Gomes, M. S. A., Bokehi, J. R. \& Castilho, S. R. (2020). Informação sobre benzodiazepínicos: O que a internet nos oferece? Ciência \& Saúde Coletiva, 25(11), 4351-4360. https://doi.org/10.1590/1413-812320202511.09632019

Rangel, N. L. \& Francelino, E. V. (2018). Caracterização do Perfil das Intoxicações Medicamentosas no Brasil, durante 2013 a 2016. Revista Multidisciplinar e de Psicologia, 12(42), 121-135. https://doi.org/10.14295/idonline.v12i42.1302

Sandilands, E. A. \& Bateman, D. N. (2016). The epidemiology of poisoning. Medicine, 44(2), 76-79. https://doi.org/10.1016/j.mpmed.2015.11.015

Savvas, S. M. \& Gibson, S. J. (2016). Overview of Pain Management in Older Adults. Clinics in Geriatric Medicine, 32(4), 635-650. https://doi.org/10.1016/j.cger.2016.06.005

Schaper, A. \& Ebbecke, M. (2017). Intox, detox, antidotes - Evidence based diagnosis and treatment of acute intoxications. European Journal of Internal Medicine, 45, 66-70. https://doi.org/10.1016/j.ejim.2017.10.019 
Research, Society and Development, v. 10, n. 8, e25810817157, 2021

(CC BY 4.0) | ISSN 2525-3409 | DOI: http://dx.doi.org/10.33448/rsd-v10i8.17157

Silva, E. V., Castro, L. L. C. \& Cymrot, R. (2010). Informação sobre o tratamento farmacológico da obesidade em sítios da internet: avaliação da qualidade. Revista Tempus - Actas de Saúde Coletiva, 4(3), 95-111. http://www.tempusactas.unb.br/index.php/tempus/article/view/882

United Nations Office on Drugs and Crime (2019). World Drug Report 2019: Booklet 3 Depressants. United Nations publication. https://wdr.u nodc.org/wdr2019/prelaunch/WDR19_Booklet_3_DEPRESSANTS.pdf

Varady, N. H., Dee, E. C. \& Katz, J. N. (2018). International assessment on quality and content of internet information on osteoarthritis. Osteoarthritis and Cartilage, 26(8), 1017-1026. https://doi.org/10.1016/j.joca.2018.04.017

Weymann, N., Härter, M. \& Dirmaier, J. (2014). Quality of online information on type 2 diabetes: a cross-sectional study. Health Promotion International, 30(4), 821-831. https://doi.org/10.1093/heapro/dau019

Wilkerson, R. G, Kim, H. K., Windsor, T. A. \& Mareiniss, D. P. (2016). The Opioid Epidemic in the United States. Emergency Medicine Clinics of North America, 34(2), e1-e23. https://doi.org/10.1016/j.emc.2015.11.002

Yeung, T. M. \& D'Souza, N.D. (2013). Quality analysis of patient information on surgical treatment of haemorrhoids on the internet. Annals of the Royal College of Surgeons of England, 95(5), 341-344. https://doi.org/10.1308/003588413X13629960045670 